ПУБЛІЧНО-УПРАВЛІНСЬКИЙ ПІДХІД ДО ФОРМУВАННЯ ГРОМАДЯНСЬКОГО СУСПІЛЬСТВА: СУЧАСНІ ВИКЛИКИ ТА ПЕРЕПОНИ

\title{
PUBLIC ADMINISTRATION APPROACH TO THE FORMATION OF CIVIL SOCIETY: CURRENT CHALLENGES AND OBSTACLES
}

Досліджено сучасні виклики $і$ перепони публічно-управлінського підходу до фрормування громадянського суспільства. Констатовано, що знання про державно-правові закономірності $\epsilon$, передовсім, осягненням сукупності каузальних детермінант, що обов'язково виражаються у їхньому прояві. Обрунтовано, що вивчення зазначених державно-правових закономірностей управління як соціального ореномена неможливе без аналізу причин їх виникнення. Чим більше інформації про причини тієї чи іншої події, тим імовірніше адекватне формулювання змін процесів у державно-правовій ссрері. Окрім того, керуючи причинами, конструюючи їх, чи навпаки, усуваючи, можна впливати і на саму закономірність, полегшуючи чи обтяжуючи їі реалізацію. Зауважено, що таке становище дає змогу стверджувати про державно-правові закономірності управління як про обумовлені різноманітними детермінантами, що існують у момент дії. у цьому випадку багатоманітність причин обумовлює прояв будь-якої закономірності в управлінській ссрері, що безпосередньо продукуються у владних відносинах у державно-правовій сорері. Таким $є$ механізм здійснення державної влади, а отже $i$ закономірності їі фрункціонування. З'ясовано, що узгодження управлінських дій призводить до встановлення між ними вертикальних зв'язків - субординаційних відносин. Своєю чергою, налагодження між ними аналогічних горизонтальних зв'язків трактується як координація, тобто поєднання двох $і$ більше однорівневих дій, що забезпечують досягнення запланованого результату. Чим вища міра відповідності системи, що нею управляють, тим ефрективніший результат управління як діяльності. Урешті, усе це дає підстави стверджувати: управління характеризується цілісністю і діалектикою системи, що нею управляють, та системи, яка управляє їх частинами, причинно-наслідковими зв'язками між ними.

Ключові слова: публічно-управлінський підхід, людина, громадянин, суспільні відносини, громадянське суспільство, публічне управління.

The article is devoted to the study of modern challenges and obstacles of the publicadministrative approach to the formation of civil society. It is stated that knowledge of state and legal laws is, first of all, an understanding of the set of causal determinants, which are necessarily expressed in their manifestation. It is substantiated that the study of these state and legal laws of management as a social phenomenon is impossible without studying the causes of their occurrence. The more information about the causes of an event, the more likely it is to adequately formulate changes in the processes in the state and legal sphere. Moreover, controlling the causes, constructing them, or vice versa, eliminating, you can influence the law itself, facilitating or complicating its implementation. It is stipulated that this state of affairs allows us to speak of state and legal laws of management as due to the various determinants that exist at the time of action. In this case, the variety of reasons causes the manifestation of any pattern in the management sphere, directly produced in power relations in the state and legal sphere. This is the mechanism of exercising state power, and hence the laws of its functioning. It was found that the coordination of management actions leads to the establishment of vertical links between them - subordinate relations. In turn, the establishment of similar horizontal links between them is interpreted as coordination, ie, a combination of two or more single-level actions that ensure the achievement of the intended result. The higher the degree of compliance of the system that manages it, the more effective the result of management as an activity. Ultimately, all this gives grounds to assert that management is characterized by the integrity and dialectic of the system that governs it and the system that governs, their parts, the causal relationships between them. Key words: public management approach, person, citizen, public relations, civil society, public administration. Львівського державного університету внутрішніх справ

Постановка проблеми. Поняття управління та видів управлінської діяльності не завжди характеризуються наявністю юридичного визначення. Утім, де-факто існує стільки ж, скільки й механізм і апарат держави. Управління, особливо радянського та пострадянського періодів, сприймалося у суспільстві дещо негативно, позаяк асоціювалося як мінімум із формалізмом та бюрократією, як максимум - із примусом і репресією. Відтак жодним чином не асоціюється із уміннями сприяти формуванню чогось демократичного та самоорганізуючого. Вкорінення подібних переконань у суспільстві відбувалося не без участі прибічників насильницької теорії походження державної влади, які одностайно стверджували, що будь-яке управління - це віолентне означення суспільства, тому характеризується руйнівним впливом на громадськість і розкриває корисливі мотиви влади тощо. Натомість у державах західної демократії було прийнято називати управління менеджментом - тобто, організацією, і подавати її сутність, спираючись на засади координації, а не субординації. Це зумовило виникнення та діяльність великої кількості неурядових громадських організацій, а також організацій, що зареєстровані як об'єднання жителів певної громади та утворю- 
ють діалектичну взаємодію із публічним управлінням [6, с. 118-119].

Отож, управління у суспільних відносинах повинно ґрунтуватися винятково на демократичних засадах субординації, виражаючи волю панівної більшості населення із залученням громадськості. Лише за таких умов може йтися про його режим сприяння розвитку громадянського суспільства. Водночас, попри всі перестороги та нарікання послідовників критики управління як феномена, слід зазначити, що не існує суспільства без управління, як немає управління без політичного лідерства, політичної волі, політичного авторитету. Політична еліта в цьому ракурсі і постає як властивість соціальної організації суспільства.

Аналіз останніх досліджень і публікацій. Вирішення окреслених у науковій розвідці завдань передбачає аналіз праць учених, які безпосередньо чи опосередковано досліджували формування громадянського суспільства в контексті його публічно-управлінського виміру. Посилання на їхні праці відображено у тексті статті з обґрунтуванням основ, що стали теоретико-методологічним підґрунтям презентованого дослідження. Відтак метою статті є вивчення сучасних викликів і перепон публічно-управлінського підходу до формування громадянського суспільства.

\section{Виклад основного матеріалу.} Акцентування управління на громадянському суспільстві може проявлятися у тому, що, як відзначає Л. Дунаєва, управління - це особлива соціальна функція, що виявляється у саморегулюванні суспільних відносин і характеризується супроводом усієї історії людства. Цьому процесу властиво володіти різними формами, методами, специфікою залежно від історичного періоду, в якому вони здійснюються [4, с. 646]. Окрім того, зміст цього процесу поєднує у собі вплив, регулювання, координацію, контроль, поєднання тощо.

Історії відомо різні моделі взаємин публічного управління та громадянського суспільства, що визначаються 3 урахуванням особливостей просторово-часового континууму. Зокрема, найпоширенішими типами соціального управління $є$ : ліберальна модель, або американська, неоліберальна модель (германський тип), власне європейська модель, соціальна модель, або скандинавська, далекосхідна модель [1, с. 124]. Звісно, різні держави, правові системи та правові сім'ї формують власну концепцію взаємин усередині взаємодії управління та громадянського суспільства. То чи не належить до сучасних викликів сформулювати власну мікромодель із їі імплементацією до конкретної світової макромоделі з переліку зазначених? Проте практично це завдання виглядає складнішим, аніж у теорії, адже історичні реалії минулого пов'язують правовий менталітет українців із абсолютно різними моделями, а відтак і методами.

Методи управління всередині цих моделей теж суттєво відрізняються, ще й залежно від зазначених моделей управління. Вони, як важелі впливу, закономірно спрямовані на досягнення мети останньої, а відтак - забезпечення необхідних умов, за яких умови для реалізації етапів-функцій державного управління були б найбільш сприятливими. Відтак ефективність і гарантія максимальної продуктивності управління - це основна характеристика методів. Одначе, як відомо, мета може виправдовувати або ж не виправдовувати засоби, а це вказує на те, що управління може бути гуманного спрямування, тобто такого, що зважає на особливості потреб його суб'єктно-об'єктного складу, або ж управління авторитарного чи бюрократичного характеру, де істині потреби більшості членів суспільства нівелюються.

Управління поєднує різні функції, а також характеризується наявністю об'єкта та суб'єкта. Звісно, суб'єктом управління завжди є людина, спільнота тощо, а об'єктами постають поведінкові акти, поведінка й діяльність людей та їх об'єднань. Відтак вектор соціального управління спрямований від людей та колективів до людей та колективів. Утім, об'єктом ніколи не постає людина, а результат людської життєдіяльності.

Поза суб'єктом та об'єктом не менш важливим аспектом постає мета управління. Адже властиво для її реалізації існує процес управління. Так, мета постає сутністю самого процесу управління і, в цьому також полягає важливість процесу управління - з'ясування відповідності мети процесу управління із його сутністю. Отже, закономірно, що управління та панування визначає форму та напрям розвитку суспільного життя. Без цього суспільного духу, без морального наповнення, який проявляється у життєдіяльності політичного організму, держава залишається лише бездушною формою, засобом для збереження матеріальної безпеки [7, с. 334].

Попри те, навіть поверхнева єдність і зовнішнє підпорядкування нормам без внутрішньої монолітності не надає управлінській функції реалізації. Для встановлення злагодженої покірності суспільства внаслідок підпорядкування необхідне об'єднання людей, пов'язаних загальними переконаннями, або інтересами, таких, що діють заодно. На цьому тримається вся суспільна сила. Також важли- 
вою диференційною засадою слід вважати те, що, мовлячи про необхідність зазначеного морального порядку в суспільстві, неможливо говорити про те, що кожен громадянин неодмінно має бути згідний із панівною управлінською політикою, чи особи, індивідуальні чи колективні, неодмінно повинні розділяти точку зору один одного тощо.

Адже переконання і погляди ґрунтуються на духовно-культурних і ментальних особливостей людини/людей, і вимагати від усіх членів суспільства однакових поглядів можна лише за умови повного знищення демократичних свобод, принижуючи людську гідність, завдаючи шкоди цілісному розвитку суспільства. Для того, аби впорядковувати, збалансовувати суспільні інтереси, визначати їх переваги, реалізовуючи в такий спосіб делеговані йому суспільством і визначені державою компетенцію та функції, й існує публічне та державне управління. Отже, говорячи про відносини управління-підпорядкування, ми простежуємо діалектику двох начал: якщо необхідність покори і підпорядкування може обмежувати свободу, то остання в своєму необмеженому вигляді може підривати основи суспільного порядку.

Суспільство, розділене в переконаннях, в якому змагаються світогляди один одного, без об'єднувального управлінського впливу апріорі не можуть жити нормальним прогресуючим темпом. Ба більше, навіть його формальне існування обмежене у часі та приречене. Саме в цьому випадку публічне управління активізує основне завдання: як зробити так, аби абсолютна свобода індивідуальної чи колективної особи була обмежена винятково до необхідної для суспільства міри, відшліфувати її до сумісності із панівним суспільним порядком, де індивідуальне підкоряється суспільному.

Загалом можна констатувати, що знання про державно-правові закономірності - це передовсім осягнення сукупності каузальних детермінант, що впливають на їхній прояв. Вивчення зазначених державно-правових закономірностей управління як соціального феномена неможливе без аналізу причин їх виникнення. Чим більше інформації про причини тієї чи іншої події, тим імовірніше адекватне формулювання змін процесів у державно-правовій сфері. Водночас, керуючи причинами, конструюючи їх, чи навпаки, усуваючи, можна впливати і на саму закономірність, полегшуючи чи обтяжуючи її реалізацію. Утім, зазначений процес, від появи будь-яких каузальних детермінантів і закінчуючи змінами об'єктивної дійсності, можна іменувати механізмом дії конкретно визначеної державно-правової управлінської закономірності
[2, с. 72]. Відтак випадковість у сфері державного управління розглядається як відсутність знань про державно-правові закономірності в тій сфері, де відбулася та чи інша випадкова подія, позаяк пізнання абсолютно всіх закономірностей видається неможливим. Тож багато закономірностей видаються нефіксованими [3, с. 172]. Окрім цього, узгодження управлінських дій призводить до встановлення між ними вертикальних зв'язків - субординаційних відносин, тобто підпорядкування одного суб'єкта вимогам іншого.

Установлення ж між ними аналогічних горизонтальних зв'язків - це, відповідно, координація, тобто поєднання двох і більше однорівневих дій, що забезпечують досягнення запланованого результату. Що вища міра відповідності системи, що нею управляють, то ефективніший результат управління як діяльності. Це дає підстави стверджувати, що управління характеризується цілісністю і діалектикою системи, що нею управляють, і системи, котра управляє, їх частинами, причинно-наслідковими зв'язками між ними тощо. Динаміка функціонування цих систем указує на спланованість діяльності, що спрямована на забезпечення оптимального функціонування і розвитку об'єкта управління. Окрім цього, слід зазначити, що не існує суспільства без управління, як і немає управління без політичного лідерства, політичної волі, політичного авторитету. Політична еліта в цьому ключі виконує роль властивості соціальної організації суспільства. Зрештою, це питання вказує і на те, що управління у суспільних відносинах повинно здійснюватися винятково на демократичних засадах субординації, виражаючи волю панівної більшості населення, а отже взаємодіяти із громадянським суспільством.

Охарактеризувавши взаємодію управління та громадянського суспільства як феномена, спробуємо описати їх співвідношення як процесів. Загалом управління як процес - це система поведінкових актів людини, які спрямовані на досягнення системного кінцевого результату. Зазначена система поведінкових актів є зв'язком взаємообумовлених перманентно змінювальних один одного елементів, які можна охарактеризувати як завдання. Такі завдання логічно об'єднати у дві основні групи: базові та похідні, або згруповані. Основними серед таких є: стимулювання, структуризація, моніторинг, організація діяльності. Лише постановка та логічне слідування кожному із завдань надає змогу досягти бажаної мети у повному обсязі. Таким чином, слід зазначити, що основною засадою управлінської діяльності можна вважати неухильне дотримання 
кожного із завдань як алгоритмічної формули, зважаючи на те, що ці завдання-функції є водночас етапами процесу.

У контексті вивчення взаємодії управління та громадянського суспільства слід брати до уваги психологічні особливості суб'єктів управлінської діяльності та об'єкт впливу. Позаяк будь-який стиль і вид управління, поза його суб'єктивними та інтерсуб'єктивними факторами, передбачає взаємодію і є процесом передовсім абстрактним і ментальним, тобто таким, що розпочинає свої первісні етапи у свідомості людей. Окрім того, його результат залежить від властивостей мисленнєвих процесів людини та від чіткості усвідомлення обраної мети, можливості структурувати окреслені етапи-завдання тощо.

Якщо управління спрямоване на досягнення мети, іманентно та перманентно невластивій певному соціуму, то воно руйнуватиме соціум, групи та окремих осіб, характеризуватиметься узурпацією і деструкцією, здатністю до поступового саморуйнування. Скажімо, завдання-етап мотивації передбачає пошук виявлення актуальних проблем, що чітко властиві конкретному суспільству, акцентуації на громадських потребах, які годиться вирішити. Утім, виявлення коректних цілей подібно до правильної постановки діагнозу, визначає подальші властивості та тенденції управлінського процесу.

Наступний завдання-етап - структурування - виокремлює мікроетапи серед етапів на шляху до досягнення кінцевої мети. Для моніторингу важливо вміти адекватно співвіднести отримані результати із задекларованими, бажаними, а також, що не менш важливо, сконструювати попередню схему допустимих відхилень поміж задекларованим, бажаним та отриманим. Відтак, коли теоретична конструкція управління скомпонована, можна вдаватися до конструкції та втілення управлінської діяльності. Вона вимагає наявності ресурсів чотирьох основних видів: людських, часових, інформаційних та матеріально-фінансових.

Також, не слід забувати і про самоуправління як мікрофеномен і мікропроцес управління загалом. Самоуправлінням можна вважати концентрацію зазначених ресурсів і структуризацію завдань-етапів, що спрямовані індивідуальною чи колективною особою на себе, тобто на громадянське суспільство загалом та його членів зокрема. Мета самоуправління, спрямованого на власну особу, - покра- щення особистих властивостей та поліпшення життєдіяльності чи індивідуальної чи колективної особи: колективу, об'єднання, громади певної територіальної одиниці тощо. Якщо ж самоуправління призводить не до покращення особистих властивостей та показників якості життєдіяльності, цей процес апріорі не визначається самоуправлінням, а $€$ ентропійним, тобто таким, що спрямований на регрес і руйнацію [5, с. 323]. Врешті, основними рисами позитивного антиентропійного самоуправління є: позитивний характер, спрямованість і збереженість структурності означеної системи, націленість на підвищення її стабільності та поліпшення показників якості, покладання на себе відповідальності за власні дії та перманентне слідування кінцевій позитивній меті.

Висновки. Підсумовуючи, доцільно ствердити, що основний виклик перед публічним управлінням як феноменом і процесом - це найперше сприяння становленню громадянського суспільства, його самоуправлінських властивостей, а також формування ментально властивої українському суспільству моделі взаємодії та архетипіки управління. Означений процес можна реалізувати лише за умови врахування управлінської традиції та її гармонізації із привілейованими в сучасному світі, актуальними і результативними моделями, описаними в цій науковій статті.

\section{ЛІТЕРАТУРА:}

1. Авер'янов В. Б. Державне управління: європейські стандарти, досвід та адміністративне право. Київ: Юстиніан, 2007. 288 с.

2. Ветютнев Ю. Ю. Государственно-правовые закономерности: вопросы теории и методологии: дисс. ... канд. юрид. наук: 12.00.01. Волгоград: Крейд, 2004. 215 c.

3. Гончарук С. И. Объективные законы и их отражение в фрилософии и конкретных науках. Философрия и общество. 2000. № 3. С. 170-180.

4. Дунаєва Л. Управління як соціальна функція владно організованої діяльності. Держава і право: збірник наукових праць. Серія: юридичні і політичні науки. 2011. Вип. 51. С. 683-688.

5. Словник-довідник для фахівців 3 питань управління та економіки; за ред. В. П. Черних. Харків: Юрінком-Інтер, 2001. 632 с.

6. Цветков В., Горбатенко В. Демократія - управління - бюрократія: в контексті модернізації українського суспільства: монографія. Київ: Ін-т держави і права ім. В. М. Корецького НАН України, 2001. 248 с.

7. Чичерин В. В. О народном представительстве. Философия права: хрестоматия; под. ред. Н. И. Панова. Киев: Ин-Юре, 2002. 692 с. 